\title{
Sukuk İhraçlarına Yeni Bir Dayanak Varlık Önerisi Olarak Elektronik Ürün Senetleri (ELÜS)
}

\author{
Fatih KAZANCI*
}

Kuveyt Türk Katılım Bankası A.Ş.

\section{Öz}

Türkiye'de ve dünyada sukuk ihraç işlemlerinin geçmişi çok kısa bir döneme yayılmıştır. Bu süreç içerisinde sukuklar pek çok çeşitli dayanak varlığa dayalı olarak ihraç edilegelmişlerdir. Günümüzde alt yapı projeleri, mal alım satımı, duran varlıklar, kullanım hakkı sahipliği ve benzerleri dayanak varlıklar olarak kullanılmaktadır. Tarıma dayalı varlıklar kullanılarak ihraç edilen sukuklar ise oldukça kısıtlıdır. Son yıllarda tarım ürünleri, Lisanslı Depo İşletmeleri'nde depolanarak karşılığında, depolanan ürünü temsil eden Elektronik Ürün Senetleri (ELÜS) düzenlenmektedir. Bu senetlerin dayanak varlık olarak kullanımı sayesinde sukuk ihraçlarına yeni bir dayanak varlık kazandırılacak, ELÜS'lerin kullanım alanı genişleyecek, ülke ziraati desteklenebilecek, sukuk ihraççıları finansman sağlayabilecek ve sukuk yatırımcıları faizsiz getiri elde edebileceklerdir. Makalede dayanak varlık olarak ELÜS kullanılarak dört farklı sukuk ihraç yöntemi modellenmiştir.

Anahtar Kelimeler: İslami Finans, Katılım Bankacılığı, Kira Sertifikası, Sukuk, Elektronik Ürün Senedi 


\title{
Electronic Warehouse Receipt (EWR) as a New Underlying Asset Proposal for Sukuk Issuance
}

\begin{abstract}
The history of sukuk issuance in Turkey and around the world has spread over a very short period. In this process, sukuks were issued based on a wide variety of underlying assets. Infrastructure projects, purchase and sale of goods, long term assets, right of use ownership etc. have been used as underlying assets in sukuk issuances. In recent years, certificates called Electronic Warehouse Receipt (EWR) representing the stored product are issued in exchange for agricultural products stored in Licensed Warehouse Enterprises. Thanks to the use of these EWR's as underlying assets, a new underlying asset will be added to sukuk issues, the usage area of EWR will expand, the country's agriculture will be supported, sukuk issuers will be able to finance and sukuk investors will be able to earn interest-free returns. Four different sukuk issuance methods are modeled using EWR as the underlying asset in the article.
\end{abstract}

Key Words: Islamic Finance, Islamic Banking, Sukuk, Islamic Bonds, Electronic Warehouse Receipts

\section{Electronic Warehouse Receipt (EWR) as a New Underlying Asset Proposal for Sukuk Issuance}

The history of sukuk issuance in Turkey and around the world has spread over a very short period. In this process, sukuk were issued based on a wide variety of underlying assets. Infrastructure projects, purchase and sale of goods, long term assets, right of use ownership etc. have been used as underlying assets in sukuk issuances. In recent years, bills called Electronic Warehouse Receipt (EWR) representing the stored product are issued in exchange for agricultural products stored in Licenced Warehouse Enterprises. These bills are given as collateral to the banks by the farmers and thus loans are obtained. In addition, these bills are also the subject of trading through the Turkish Mercantile Exchange (TMEX).

Sukuks are usually exported based on partnership, purchase and sale, management contract, works contract or lease (ownership). As main assets; infrastructure projects, purchase and sale of goods, fixed assets, ownership of the right of use, etc. structures are used. In addition to all these underlying assets, it is possible that agricultural products converted into certificates are also the main assets. Thanks to the use of these EWR's as underlying assets, a new underlying asset will be added to sukuk issues, the usage area of EWR will expand, the country's agriculture will be supported, sukuk issuers will be able to finance and sukuk investors will be able to earn interest-free returns. Four different sukuk issuance methods are modeled using EWR as the underlying asset in the article.

The aim of this study is to contribute to the issuance of new types of sukuk by participating banks by using EWR as the main asset, whose capacities and awareness are increasing day by day in Turkey. In this way, other stakeholders in the field of agriculture will also get a new opportunity for interest-free financing. 
In the article, the definition, structure, types and types of underlying assets of sukuk are described and the stages of issuance of Electronic Warehouse Receipt (EWR), parties and whether they can be used as a underlying asset are investigated. Examples issued using agricultural products as the main asset in Turkey have been described, and then a sukuk issue model has been designed that can be used for four different purposes asset based and asset backed using EWR.

\section{Model 1: Hybrid sukuk model based on Wakala and Trading}

Model 1, a sukuk model based on a management contract (wakala) and trading, can be created in two different ways. In Model 1a, the originator does not have EWR. In this sukuk issue method, the originator invests in Special Purpose Vehicle (SPV) by purchasing EWR by proxy with the price that SPV collects from sukuk investors. In issuance, sukuk investors will be partners in the profit or loss of the assets represented by sukuk.

This sukuk model is structured as a sukuk based on wakala contract. The originator will invest with the EWR it has purchased and will share the proceeds with sukuk investors. The originator will promise sukuk investors an "expected return" during the sukuk issuance phase. "Expected return" is the amount of return determined in the contract in wakala transactions and payable to the party (investor). If an income is earned above the expected amount of return at maturity, investors will be paid the same as the expected rate of return, and the remaining income will be paid to the proxy. If less than the expected return is earned, it will pay investors the entire income. In case of loss, investors will be paid by cutting from the principal money as much as the loss.

In this issue model, sukuk owned by investors can be traded in secondary markets until they are purchased and sold by the originator. Because in this case, the relevant EWR represent the existing assets.

\section{Model 2: Hybrid Sukuk model based on management agreement and Murabahah}

This sukuk model is a model that participation banks as a originator can use to meet their financing needs. In this structure, EWR will be used as the main asset. In this structure, the originator will buy EWR in advance with the amount collected by SPV from sukuk investors by murabaha method by proxy to SPV by entering into a management contract with SPV, and will generate income by selling the product to a third party that needs it in the term, and distribute the income it receives to sukuk investors.

Since this issue model is carried out based on the murabaha contract, issued sukuk can not be traded on the secondary markets after the EWR subject to murabaha is sold and delivered to a third party. Because in this case, sukuk represents of debt of the third party, not the EWR. Otherwise, these sukuk are 
evaluated according to the provision on the sale of debt in the fiqh and are not eligible for purchase and sale in the secondary markets. But before EWR are bought by the originator and sold to a third party, sukuk can be traded in secondary markets, as they represent existing assets.

\section{Model 3: Sukuk Model Based on Tawarruq/Commodity Murabahah}

This sukuk model can be used by a participation bank (originator) in need of funding. In Turkey, especially participation banks use this method to meet their financing needs. But fiqh advisory boards allow participation banks if they use this type of sukuk in a way that does not exceed $49 \%$ within the hybrid sukuk structure. Therefore, the remaining $51 \%$ is usually carried out in the management agreement or icare sukuk structure.

Currently, participating banks use the London Metal Exchange (LME) to trade commodities in sukuk issuance based on trading. In this exchange, precious metals such as platinum or palladium are usually bought and sold by brokerage brokers as commodities. However, the transactions carried out in this Exchange are not suitable in terms of figh due to the structure of the LME. According to Kazancı (2018), "Tawarruq market in accordance with the principles of interest-free banking in Turkey: Turkish Mercantile Exchange (TMEX)"; as an alternative to the London Metal Exchange, the TMEX will be able to create a tawarruq market in Turkey in accordance with the principles of participation banking. In this model, the proposed sukuk issue transaction can be carried out through the TMEX tawarruq market, which is planned to be established in 2021 .

Since the trading-based model covers a $49 \%$ rate within the hybrid structure, the trading of these sukuk issuances on the secondary market depends only on the $51 \%$ sukuk structure being suitable for the secondary market.

\section{Model 4: Sukuk Model Based on Mudharabah}

In this model, it is modeled on the issue of sukuk by establishing a mudharabah, that is, labor capital partnership with a manufacturer using EWR. According to the model, SPV will purchase and deliver EWR as capital to the manufacturer in need of agricultural raw materials. Then, the manufacturer will make production by putting his labor into effect and will share his profit with SPV according to the rate he agreed with SPV. In this structure, which is an asset-based model, sukuk can be bought and sold on the second-hand market.

The first of the proposed sukuk models is a hybrid model based on a management agreement (wakala) and trading, based on assets, can be bought and sold in the secondary market, with variable returns, does not pose a risk of default and is suitable for fiqh. But because of its variable yield, it carries a risk of financial loss. The second model is based on management agreement and murabaha and may be preferred by investors because it provides fixed 
returns, although it is an asset-based, non-secondary market, fixed income and controversial as fiqh. The third model is based on tawarruq/commodity murabahah. This model can be preferred by participation banks due to its operational simplicity, operational speed. It will be issued by trading in a legally appropriate tawarruq market in Turkey instead of a tawarruq market abroad. But it also includes the disadvantages mentioned in the second model. The fourth model is based on mudharabah method and is a model with variable returns, which can be bought and sold in the secondary market and is suitable as fiqh.

EWRs have also been used in Turkey in recent years, and the volume of EWR is increasing every year, and they can be bought and sold on the TMEX. EWR, which contributes to producers and the agricultural development of the country, is a main asset that will also be used in the issue of sukuk.

As a result of sukuk issuance using EWRs as an underlying asset;

More agricultural products will be converted to EWR, and the volume of EWR circulating in the market will increase. In this way, the agricultural sector will be further supported.

Producers, brokers, intermediaries, cooperatives and institutions with EWR representing agricultural goods will be able to be funded.

Processed food producers who have difficulty paying the price of raw materials will be able to increase their production thanks to the mudharabah sukuk structure.

Sukuk investors will be able to make a profit by trading in secondary markets with an interest-free investment vehicle.

Participation banks will be able to increase the types of sukuk issuance by using EWR as an underlying asset and reach financing in a more appropriate way from a fiqh point of view.

With the use of EWRs as the underlying asset, financing opportunities will be provided to participation banking, farmers, food producers, brokers, intermediaries and cooperatives. Thus, sukuk investors will be able to earn interest-free profits thanks to these investments they make.

In other Islamic countries, where agricultural activities spread around the world are intense, it will be possible to issue sukuk using Paper Warehouse Receipt (PWR) or Electronic Warehouse Receipt (EWR) as the underlying asset, and thus it will be possible to contribute to the development of Islamic banking and agriculture in these countries. 


\section{Giriş}

Sukuklar genelde ortaklığa, alım satıma, yönetim sözleşmesine, eser sözleşmesine veya kiralamaya (sahipliğe) dayalı olarak ihraç edilmektedirler. Dayanak varlıklar olarak ise; alt yapı projeleri, mal alım satımı, duran varlıklar, kullanım hakkı sahipliği vb. yapılar kullanılmaktadır. Tüm bu dayanak varlıklara ek olarak senet haline getirilmiş tarım ürünlerinin de dayanak varlık olması mümkündür.

Son yıllarda çiftçiler ürettikleri tarım ürünlerini ve tarım komisyoncuları aracılık yaptıkları tarım ürünlerini Lisanslı Depo İşletmeleri aracılığıyla Elektronik Ürün Senetlerine (ELÜS) dönüştürmektedirler. Kısaca ELÜS adı verilen bu senetler çiftçiler tarafindan bankalara teminat olarak verilerek karşılığında kredi kullanılmaktadır. Ayrıca bu senetler, Türkiye Ürün İhtisas Borsası (TÜRİB) aracılığıyla alım satıma da konu olmaktadır.

Bu çalışmanın amacı, ülkemizde kapasiteleri ve bilinirlikleri gün geçtikçe artan ELÜS'lerin dayanak varlık olarak kullanılarak katılım bankalarının yeni sukuk türleri ihraç etmelerine katkıda bulunmaktır. Böylece tarım alanındaki diğer paydaşlar da yeni bir faizsiz finansman olanağına kavuşacaklardır.

Makalede sukuk tanımı, yapısı, türleri ve dayanak varlık çeşitleri anlatılmış olup, Elektronik Ürün Senedinin ihraç aşamaları, tarafları ve dayanak varlık olarak kullanılıp kullanılamayacağı araştırılmıştır. Türkiye'de tarım ürünleri dayanak varlık olarak kullanılarak ihraç edilen örnekler anlatılmış olup, akabinde ELÜS kullanılarak varlığa dayalı ve varlık temelli dört farklı amaçla kullanılabilecek sukuk ihraç modeli tasarlanmıştır.

\section{Literatür Değerlendirmesi}

Yapılan litaretür taramasında Elektronik Ürün Senetleri dayanak varlık olarak kullanılarak ihraç edilmiş sukuk yapılarına rastlanmamış olup, tarımı ve çifçileri desteklemek amacıyla gerçekleştirilen sukuk ihraçları ile ilgili araştırmalardan bazılarına aşağıda yer verilmiştir.

Konu ile ilgili sukuk ihraçlarını araştırdığımızda; Beik ve Hafidhuddin (2008), Endonezya'da küçük ölçekli tarım yapanlar için hem yerel hem de uluslararası ticaretle ilgili iki model önermektedir. Bu modeller selem temelli sukuklardır. Büyük ölçekte tarım yapanlar için ise mudarabah bil istisna sözleşmesine dayalı sukuk ihraçları önerilmektedir. Bu ihraçların gerçekleşmesi için İslami Bankacılık Kanunu ve Sukuk Kanunu'nu içeren kapsamlı bir politika paketi 
sayesinde Endonezya'daki İslami sermaye piyasası ile tarım sektörü arasındaki entegrasyonun sorunsuz bir şekilde çalışacağı öngörülmüştür.

Anisa ve Santoso (2020) makalelerinde, yerel yönetimlerin tarıma yönelik sukuk ihraçlarında selem sukuk yapısını kullanabileceğini belirtmiştir. Selem sukuk sözleşmelerine pirinç, mısır ve çay gibi tarım ürünlerinin konu olabileceğini ve elde edilen fonların üretime başlamak için sermaye olarak kullanılabileceğini ifade etmişlerdir. Selem sukukun yerel yönetimler tarafından ihraç edilmesi sayesinde bu sertifikaların devlet sukuklarına göre daha çok talep göreceğini ve elde edilen fonların insanların refahını iyileştirmek için kullanılabileceğini ifade etmişlerdir.

Soeleman ve Lestari (2015) ise, son yıllarda popüler olan araçlardan birinin, kârın yatırımcılar arasında önceden belirlenen bir orana göre paylaşılacağı sukuklar olduğunu ve yatırımcılar, kalifiye işçiler, çiftçiler ve arazi sahipleri gibi paydaşlar arasında sukuka dayalı kâr paylaşımının tüm kriterlerde maaşlı ücretlere göre daha iyi bir çıktı sağladığı sonucuna varmışlardır. Fakat bu paydaşların elde edecekleri gelirin, faaliyetlerden elde ettiklerinden kârdan sonra alınacağını da unutmamak gerekmekte olduğunu not olarak eklemişlerdir.

Türkiye'de ELÜS piyasaları ile ilgili literatür incelendiğinde aşağıdaki araştırmalara rastlanmıştır:

Gün ve Tahsin (2019) makalelerinde; spot ve vadeli ELÜS piyasasındaki kurumsal mekanizmalar uluslararası standartlara benzer olsa da ELÜS bazlı ticaret hacminin Türkiye'de çok düşük bir seviyede olduğunu ve emtia piyasalarında resmi ve özel kurumlar arasında güçlü bir uyum olmadığı sonucuna varmışlardır. Lisanslı depoculuk sistemi ile ilgili mevzuat on yıl öncesinde yayınlanmış olsa da sistemin henüz hem kullanım hem de kapasite olarak istenen seviyeye ulaşamamış olduğunu belirtmişler, ayrıca sağlanan verilere göre; vadeli ELÜS alım satım işlemleri henüz gerçekleştirilememiş ve üretilen tahılın çok küçük bir kısmının spot ELÜS ticaretinde tabi olduğunu ileri sürmüşlerdir. Fakat son yıllarda devletin desteği ile önemli adımlar atılmış ve spot ELÜS ticaretinde önemli artışlar yaşanmakta olduğunu, Ürün İhtisas Borsası'nın kurulmasının spot ELÜS piyasasının derinleşmesine katkı sağlayacağını ve derinleşen bu piyasa sayesinde vadeli tarım sözleşmelerinin piyasa katılımcıları tarafından kullanılmaya başlanacağını ifade etmişlerdir.

Çelimli ve Adanacıoğlu (2016) ise makalelerinde, küçük ölçekli olan, yatırım yapmak isteyen ve güven sorunu yaşayan yatırımcılar için ELÜS'lerin cazip bir yatırım aracı olma potansiyeline sahip olduğunu, bu nedenle ELÜS işlemlerinin kamuoyuna iyi lanse edilmesi gerekliliğini ifade etmektedirler. Türk yatırımcısı için yeni bir yatırım aracı olan ELÜS'lere yatırım yapılması için bir ısınma dönemine ihtiyaç olduğunu ve öncelikle reel sektörün bu piyasada işlem yapmasının sağlanması gerektiğini ve piyasa sağlıklı işledikçe bu 
enstrümana bankaların da ilgisinin artacağını öne sürmüşler ve bu piyasanın gelişiminin tarım bankacılı̆̆ını da geliștireceğini eklemişlerdir.

\section{İslami Bir Finansal Araç: Sukuk}

Günümüzde sukuk, terim olarak bir hizmet, mal, kullanım hakkı veya bir yatırımın mülkiyetine dair eşit değerlere sahip hisseli belgeler olarak tanımlanabilir (Cebeci, 2016: 529). İslami sermaye piyasalarının tahvile eş değer modern ismi sukuktur. Sukuk kelimesi yatırım sertifikası anlamına gelebilecek olan "sakk" kelimesinin çoğuludur. Sukuk, bir "güven belgesi" olarak da tercüme edilebilir. Bu belge, Ortaçağ Müslümanlarının ticari aktivitelerden kaynaklanan mali yükümlülüklerini kanıtlayan belgeler olarak kullanılmışlardır. Ortaçağda sakk kullanımı tartışılmış ve ilgili dönemde askerlere ve devlet memurlarına kısmi bir ödeme yapmak amacıyla kullanılmıştır. Yaygınlaşan bu sertifikalar tahıl izinleri olup, sahiplerine vadesinde devlet hazinesinden önceden belirlenen miktarda emtia alma hakkı veriyordu. Sakk, bir devlet yükümlülüğünü temsil ettiği için genellikle sukuk sahipleri arasında sıklıkla ticari amaçla takas edilirdi.

Sukuk piyasalarının uyması gereken kendilerine özgü kuralları şunlardır:

- Sukuk ihracı yoluyla toplanan tüm fonlar, fikhi açıdan uygun faaliyetlerde kullanılabilir.

- $\quad$ Fonlar maddi bir varlık elde etmek için kullanılırsa, bu durumun net bir şekilde tanımlanması gerekir. Çünkü sukuk, tahvillerin aksine ihraççının genel finansal ihtiyaçlarını karşılamak için kullanılamaz.

- Sukuk hissedarlarının aldıkları her türlü gelir, sadece dayanak varlık tarafından üretilen nakit akışlarından elde edilmelidir.

- Sukuk sahipleri, dayanak varlığın ve nakit akışlarının mülkiyetinin kullanma hakkına sahiptirler. Bu durum sukuku normal bir tahvilden hibrit bir tahvil şekline sokar.

- IŞslemin tüm taraflarının özellikle de yatırımcıların ve düzenleyicinin yükümlülük ve haklarının açık ve şeffaf bir şekilde belirtilmesi gerekir.

- $\quad$ Tüm diğer İslami finans enstrümanlarında olduğu gibi sukuk, sabit bir getiri sunmamalıdırlar.

Sukukların risk getiri profili geleneksel tahvillerden çok farklıdır. Öncelikle sukukta sabit kupon ödemeleri yoktur. İkincisi, vade sonunda itfa bedeli sabitlenmez. Üçüncüsü, yatırımcının getirisi sukukun altında yatan varlığın getirdiği nakit akışları yani kazançlarla ilişkili olup, şirketin performansı ile ilişkili değildir. Bu farklılıklar sayesinde sukuk riski, ihraççıdan ziyade dayanak varlığa veya projeye bağlıdır (Rizvi ve diğ., 2016: 51).

Sukuk, farklı nominal değerlerde, farklı para birimlerinde ve farklı vadelerde ihraç edilebilir. Konvansiyonel menkul kıymetlere benzer şekilde sukuk, farklı yatırımcı türleri için yapılandırılabilir, derecelendirilerek kote edilebilir, 
bazıları ikincil piyasada alınıp satılabilir, yeniden yapılandırılabilir ve değişik varlık çeşitlerine karşı teminat altına alınabilir (İSEDAK, 2019: 9).

\section{Sözleşme Çeşitlerine Göre Sukuk Türleri}

Sukuk ihraçları pek çok çeşit sözleşme çeşidine göre sınıflandırılmakta olup, Sermaye Piyasası Kurulu'nun ve AAOIFI'nin belirlediği sözleşme çeşitlerine göre sukuk türleri aşağıda belirtilmiş ve buna ek olarak genel olarak kullanılan sukuk türlerine de yer verilmiştir.

\section{a. Sermaye Piyasası Kurulu'na (SPK) Göre Sukuk Türleri}

2013 yılında Resmi Gazete'de yayınlanan Kira Sertifikaları Tebliği'ne göre; sukuk (kira sertifikası) türleri beş maddeye ayrılmıștır. Bu Tebliğ'e göre kira sertifikaları;
1. Sahipliğe,
2. Yönetim sözleșmesine,
3. Alım satıma,
4. Ortaklı̆̆a,
5. Eser sözleșmesine,

dayalı olarak ya da bu türlerin bir arada kullanılmasıyla Varlık Kiralama Şirketleri (VKŞ) tarafından ihraç edilebilirler.

Tebliğe göre; sahipliğe dayalı kira sertifikaları, kaynak kuruluşa ya da üçüncü kişilere kiralanmak ya da Varlık Kiralama Şirketi (VKŞ) adına yönetilmek amacıyla VKȘ tarafından kaynak kuruluştan devir alınacak hak ve varlıkların finansmanını sağlamak amacıyla ihraç edilirler. Yönetim sözleşmesine dayalı ihraç edilecek kira sertifikaları, kaynak kuruluşun sahip olduğu hakların veya varlıkların (vade süresince kiralanması da dahil olarak) VKŞ lehine yönetilmesi ve sonuçta elde edilen gelirin sözleşme hükümlerince VKŞ’ye aktarılması için ihraç edilirler. Alım satıma dayalı kira sertifikaları bir hak ya da varlığın VKŞ tarafından satın alınıp VKŞ kurabilecek nitelikteki bankalar, aracı kurumlar, ipotek finansman kuruluşları gibi şirketlere vadeli olarak satılması işleminde hak ya da varlık alımının finansmanını sağlamak amacıyla ihraç edilirler. Ortaklığa dayalı kira sertifikaları, VKŞ’nin ortak bir girişime ortak olmak için ihraç ettiği sertifikalardır. Eser sözleşmesine dayalı kira sertifikaları ise iş sahibi olarak bir VKŞ’nin taraf olduğu eser sözleşmesi kapsamında eserin gerçekleștirilmesini sağlamak için ihraç edilirler (Resmi Gazete, 2013, Sayı: 28670).

\section{b. AAOIFI'ye Göre Sukuk Türleri}

AAOIFI (2010), 9 ana sukuk türü sıralamıştır. Bunlar;

1. Kiradaki Varlıkların Aslına Malik Olmayı Sağlayan Sukuklar

2. Menfaate Malik Olmayı Sağlayan Sukuklar 
3. Selem Akdine Dayalı Sukuk

4. $\quad$ Eser Sözleşmesi/İstisna Akdine Dayalı Sukuk

5. Murabaha Akdine Dayalı Sukuk

6. Ortaklı̆̆a Dayalı Sukuk

6.1. Sermaye/Müşareke Ortaklı̆̆ına Dayalı Sukuk 6.2.Emek-Sermaye/Mudarabe Ortaklığına Dayalı Sukuk 6.3.Yatırım Vekaletine Dayalı Sukuk

7. Müzaraa Ortaklığına (Ziraat Ortakçılığı) Dayalı Sukuk

8. Müsakat Ortaklığına (Bă̆-Bahçe Ortakçılığı) Dayalı Sukuk

9. Muğarase Ortaklığına (Ağaç Dikip Yetiştirme Ortakçılı̆̆ı) Dayalı Sukuk.

\section{c. Genel Sukuk Türleri}

Sukuk yapısının seçimi değişik faktörlere bağlıdır. Dayanak varlığın niteliği, vergilendirme, kanunlar, hedeflenen yatırımcı tabanı, ve ihracı onaylayacak olan danışma kurulunun görüşleri sukuk yapısının türünün seçimini etkileyen unsurlardır.

Genel olarak kullanılan sukuk türleri:

1. Icare Sukuk

2. Vakale Sukuk

3. Mudaraba Sukuk

4. Muşaraka Şukuk

5. Istisna Sukuk

6. Murabaha Sukuk

7. Selem Sukuk (Latham and Watkins, 2015).

Bu sukuk türlerinin isimleri ile SPK Tebliği'nde belirtilen sukuk türlerinin isimleri farklılık göstermektedir. Sayılan tüm sukuk türlerine ek olarak karma (hibrit) sözleşmeli sukuk türü de günümüzde yaygın olarak kullanılmaktadır. Hibrit sukuk yapısında çeşitli sukuk türleri biraraya getirilerek bir varlık havuzu oluşturulur. Mesela yönetim sözleşmesi ve alım satım sözleşmesi gibi iki farklı sözleşme türü kullanılarak bir hibrit sukuk ihracı gerçekleştirilebilir. Aşağıdaki Tablo 1'de; SPK ve AAOIFI'ye göre sukuk türleri ve genel sukuk türleri karşılaştırmalı olarak verilmiştir. 
Tablo 1: Farklı Kurumlara Göre Sukuk Türlerinin Karşılaştırılması

\begin{tabular}{|l|l|l|}
\hline SPK'ya Göre Sukuk Türleri & AAOIFI'ye Göre Sukuk Türleri & Genel Sukuk Türleri \\
\hline Sahipliğe Dayalı Sukuk & $\begin{array}{l}\text { Kiradaki Varlıkların Aslına } \\
\text { Malik Olmayı Sağlayan Sukuk }\end{array}$ & İcare Sukuk \\
\hline $\begin{array}{l}\text { Yönetim Sözleşmesine Dayalı } \\
\text { Sukuk }\end{array}$ & $\begin{array}{l}\text { Yatırım Vekâletine Dayalı } \\
\text { Sukuk }\end{array}$ & Vakale Sukuk \\
\hline Alım Satıma Dayalı Sukuk & $\begin{array}{l}\text { Murabaha Akdine Dayalı } \\
\text { Sukuk }\end{array}$ & Murabaha Sukuk \\
\hline Ortaklığa Dayalı Sukuk & $\begin{array}{l}\text { Mudaraba veya Muşaraka } \\
\text { Akdine Dayalı Sukuk }\end{array}$ & $\begin{array}{l}\text { Mudaraba veya Muşaraka } \\
\text { Sukuk }\end{array}$ \\
\hline $\begin{array}{l}\text { Eser Sözleşmesine Dayalı } \\
\text { Sukuk }\end{array}$ & İstisna Akdine Dayalı Sukuk & İstisna Sukuk \\
\hline & Selem Akdine Dayalı Sukuk & Selem Sukuk \\
\hline
\end{tabular}

Kaynak: Resmi Gazete, 2013, Sayı: 28670; AAOIFI, 2010; Latham and Watkins, 2015.

\section{Dayanak Varlık Çeşitlerine Göre Sukuk}

Sukuk, sahibine bir varlığın ya da varlık havuzunun mülkiyetini veya varlık ya da varlık havuzunun nakit akışı ile ilgili bir hak sahipliği verdiği için teoride bir hisse senedi türü olarak değerlendirilebilir. Sukuk işlemlerinde dayanak varlıklar, fikhen uyumlu varlıklar olmak zorundadırlar.

Dayanak varlıklar aşağıdaki varlık çeşitlerinde olabilirler:
1. Maddi duran varlıklar.
2. Kullanim hakları.
3. Gelir getiren hizmetler.
4. Maddi olmayan duran varliklar.
5. Fıkhi açıdan uygun malların satışlarına ilişkin alacaklar.
6. Belirli proje ya da yatırımların varlıkları.

Uygulamada sukuk çeşitlerinin tamamı varlığa dayalı değillerdir. Bazıları tam anlamıyla varlığa dayalı olarak ihraç edilebilirlerken, bazılarına sınırlı derecede mülkiyet hakkı verilmekte, bazılarına ise sadece bir referans havuzuna ya da teminat varlıklarına atıfta bulunulmaktadır (ISEDAK, 2019: 11).

Genel anlamda sukuk, varlığa dayalı (asset backed) ve varlık temelli (asset based) olarak ihraç edilir. Varlığa dayalı sukuk, likit olamayan varlıkların, likit menkul kıymetler sayesinde nakde dönüştürülmesini sağlar. Varlık temelli sukuk ise dayanak varlığın satışının yapılmadan ihraç edilmesidir.

\section{a. Varlığa Dayalı (Asset Backed) Sukuk}

Varlığa dayalı sukuk yapısında, dayanak varlıktan kaynaklı kâr ve zarar riski yatırımcı ile paylaşılmakta olduğundan, değişken getiri sağlar ve temerrüt riski tașımaz. Yatırımcılar dayanak varlığa katılım yaparak dayanak varlıktan 
kaynaklı gelir riskine ortak olurlar. Dayanak varlıkların kaynak kuruluş tarafından gerçek satışı ile VKŞ’ye devredilmeleri bu yapının bir özelliğidir. Sukuk yatırımcıları dayanak varlığın VKŞ üzerinden kendilerine devredilmesi sayesinde tam anlamıla varlığa malik olurlar. Bu sayede yatırımcılar sahip oldukları sukukları devretme hakkına da sahip olmaktadırlar. Varlığın VKŞ’ye tam devri nedeniyle varlık, kaynak kuruluşun bilançosunda görünür.

Dayanak varlıklar maddi ve belirli varlıklar olabilecekleri gibi alacak hakkı da dayanak varlık olabilir. Varlığa dayalı ihraç edilen sukuk, sahiplerine alacak hakkından çok, hisse senedine benzer bir şekilde katılım veya bir çeşit mülkiyet hakkı sağlamaktadır. Varlığa dayalı ihraç edilen sukuk, kâr zarar paylaşım esaslı olması ve getiri garantisi vermemesi sebebiyle fikhi açıdan uygundur. Mudaraba ve muşaraka sukuk yapısı varlığa dayalı sukuka örnek olarak verilebilir (Aktaș, 2016: 473-475).

\section{b. Varlık Temelli (Asset Based) Sukuk}

Varlık temelli sukuk, dayanak varlığın gerçek satışı yapılmadan ihraç edilen sukuktur. Yatırım finansmanı amaçlı olarak kullanılmakta olup, sabit getirili sukuklardır. Kaynak kuruluş bakımından bilanço içi sukuklar olup, bu sukuk yapısında temerrüt riski yüksektir. Bu yapıda dayanak varlığın yararlanma mülkiyetinin sukuk yatırımcılarına devri söz konusudur, VKŞ'ye gerçek satış yapılmamaktadır ve dayanak varlığın yasal mülkiyet hakkı kaynak kuruluşta kalmaktadır. Yani kaynak kuruluş yatırımcılara sadece VKŞ’nin yararlanma hakkının mülkiyetini devreder. Bu nedenle yatırımcıların dayanak varlık yerine sadece kaynak kuruluşa rücu hakları söz konusu olmaktadır.

Varlık temelli sukuk yapısında, yatırımcılara yapılacak ödemelerin kaynağı dayanak varlık değil, kaynak kuruluşun nakit akımı olmaktadır. Bu yapıda borç ilişkisindeki alacaklar bir havuzda toplanarak bunların gelirlerine dayanarak ihraç gerçekleştirilir. VKŞ, ihraçtan sağladığı kaynak ile dayanak varlığı satın alır ve sonra bu varlığı yatırımcıları temsilen yatırım, ticaret ya da kiralama işlemine konu eder. Murabaha, icâre, selem ve istisna sukuk çeşitleri varlık temelli sukuk ihraçlarına örnek olarak gösterilebilir.

Varlık temelli sukuk yapısında "bey'ud deyn" adı verilen "borç satışı" yapılması ve "bey'ul ine" adı verilen "çifte satış" içerebilmesi sebebiyle bu yapı fıkhen uygun bir sukuk ihracı sayılmayabilir (Aktaş, 2016: 473-476).

\section{Elektronik Ürün Senetleri (ELÜS)}

Kısaca ELÜS olarak adlandırılan Elektronik Ürün Senetleri, ürünlerin mülkiyetini temsil etmekte ve rehnini temin etmektedir. ELÜS, Lisanslı Depo İşletmesi tarafından nama ya da emre düzenlenebilen kıymetli evrak hükmünde bir senettir. ELÜS, bir kayıt kuruluşunda elektronik bir ortamda kaydi olarak saklanabilmekte ve basılı ürün senetleriyle aynı hak ve yükümlülüklere sahip olmaktadır (Köprü, 2015). ELÜS ile ilgili ilk yönetmelik 12 Kasım 2011 
tarihinde Resmi Gazete'de yayımlanmıştır. Resmi Gazete'de ELÜS, Lisanslı Depo İşletmesi tarafından elektronik kayıt kurallarına uygun olarak sistem üzerinden oluşturulan elektronik bir kayıt olarak tanımlanmıştır (Resmi Gazete, 2011, Sayı: 28110).

Elektronik Ürün Senetleri, Ticaret Borsaları'yla sözleşme imzalamış olan Lisanslı Depo İşletmeleri tarafından ilgili depoya teslim edilen tarım ürünlerini temsilen elektronik kayit kurallarına uygun bir şekilde oluşturulur ve Merkezi Kayıt Kuruluşu'nda (MKK) mudiler yani yatırımcılar adına açılan hesaplarda izlenirler (Takasbank, 2020a).

ELÜS'lerin bankalara ve üreticilere sağladığı avantajlar şöyle sıralanabilir:

- $\quad$ Bu senetler, tarım ürünlerinin alım satımı kolaylaştırır.

- Borsada alınıp satılabilen bu senetler sayesinde ürünler sağlıklı ve güvenilir bir ortamda saklanabilir ve ürünlerin yerleri değișmeden sahiplikleri değiștirilir.

- $\quad$ Bu senetler bankalardan kredi almak amacıla çiftçiler ve aracılar tarafindan bankalara teminat (rehin) olarak verilebilir.

- $\quad$ Bankalar açısından bu senetlerin teminata alınmaları teminat riskini azaltır.

- $\quad$ Bu senetler; altın, döviz ve hisse senedine benzer șekilde yatırım amacıla kullanılabilir (Gümrük ve Ticaret Bakanlığı, 2017).

Tüm bunlara ek olarak, ELÜS'ler sayesinde; tarımsal ürünler, sınıf ve kalitelerine göre tasnif edilebilmekte ve gerçek değerleri üzerinden pazarlanabilirler.

ELÜS'ler 2019 yılı öncesine kadar ülke geneline yayılan çeşitli Ticaret Borsaları'nda işlem görmekte idiler. Ticaret Borsaları, Türkiye Ürün İhtisas Borsası A.Ş. (TÜRİB) çatısı altında birleştirilmiştir. TÜRİB, 06 Nisan 2017 tarihli ve 30030 sayılı Resmî Gazetede yayımlanan 2017/9986 sayılı Bakanlar Kurulu Kararına istinaden 08.06.2018 tarihinde kurulmuş olup, 2019 yllı sonrasında ELÜS'ler, kısaca TÜRİB adı verilen Borsa'da işlem görmektedirler (TÜRİB, 2020).

Geçmiş yıllarda Ticaret Borsaları ve TÜRİB'de işlem gören ELÜS'lere ait işlem adedi ve işlem hacim bilgisi aşağıdaki Tablo 2'de verilmiştir. 
Tablo 2: Borsalarda İșlem Gören ELÜS İşlem Adet ve Hacimleri

\begin{tabular}{|c|c|c|}
\hline & İșlem Adedi & İsslem Hacmi (TL) \\
\hline $\mathbf{2 0 1 5}$ & 6,200 & $154,097,839.58$ \\
\hline $\mathbf{2 0 1 6}$ & 10,864 & $410,197,365.62$ \\
\hline $\mathbf{2 0 1 7}$ & 24,763 & $1,212,355,240.39$ \\
\hline $\mathbf{2 0 1 8}$ & 72,886 & $2,756,801,966.08$ \\
\hline $\mathbf{2 0 1 9}$ & 141,793 & $6,454,282,641.94$ \\
\hline $\mathbf{2 0 2 0}$ & 117,366 & $11,423,374,892.96$ \\
\hline
\end{tabular}

Kaynak: Takasbank (2020b).

\section{Dünya Genelinde ELÜS ve Benzeri Uygulamalar}

$A B D$, Kanada ve AB ülkelerininin çoğunluğu, Ukrayna ve Sırbistan vb. ülkelerin deneyimleri ürün senetleri sisteminin tarım sektörünün gelişimi için faydalı olduğunu göstermektedir (Hollinger ve Rutten, 2009: 7). Ürün senetleri kâğıt üzerine basılı olduğu durumlarda bu senet ülkelere göre değişiklik göstererek bir ya da iki parçadan oluşur. İki parçadan oluşan senetler Avrupa'da ve Latin Amerika'da daha yaygındırlar. İki parçalı senetler hem teminat amacıyla hem de emtia piyasasında kullanılırlar. Parçalardan biri emtianın mülkiyetini, diğeri ise teminat durumunu gösterir. Fakat tek parçalı senetler ticaret uygulamalarında hem daha basit hem de daha kullanışlıdırlar (USAID, 2002).

Hisse senetleri ve tahviller gibi menkul kıymetler pek çok ülkede kaydi formda üretilmekte olup, ürün senetleri ise bireysel özelliklerinden dolayı nadiren kaydi formda hazırlanmaktadırlar (Vasiljevic vd., 2014: 325). Kağıttan, elektronik ürün senedine geçiş nisbeten yeni bir uygulamadır. ABD'de 2010'lu yılların başında sadece pamuk ve bir kaç tahıl ürünü için elektronik formatta ürün senedi çıkarılmaktaydı. Yine de ABD'de elektronik ürün senetleri deneme amaçlı olarak 20 yıldır faaliyettedir. ABD pamuk endüstrisi, 1993 yılında ilk kez elektronik pamuk ürün senedi ihraç etmiştir (USAID, 2011).

Güney Afrika'da bulunan elektronik silo senedi sistemi, ihraçtan, ticarete ve teminat vermeye kadar olan tüm süreci elektronik formatta sürdürmektedir. Lisanslı depolar, depolanan mallar hakkındaki bilgileri elektronik bir veri tabanına yüklerler. Bu veri tabanı ürün senedi karşılığında borç vermek için hizmet vermektedir. Bu sisteme bankalar; ürün senedini teminat olarak almak, kaydi ürün senetlerinin alıp satmak ve müşterilere ve devlet kurumlarına bilgi vermek için doğrudan girebilirler. 
Batı Avrupa'da, ürün senetlerinin merkezi olarak kaydedilmesi yaygın değildir. Emtia borsaları bir teslim mekanizması kurmak için genelde gereken kayıtları kendileri yaparlar (Gashayie ve Singh, 2015: 46). Ukrayna elektronik ürün senedi merkezi kayıt kurumu, senetlerin kaydını tutmakta, çeşitli düzenleme ve kontrol işlevlerini yerine getirmede iyi bir örnek olarak verilebilir (Hollinger ve Rutten, 2009: 8). Sırbistan da ise, Tarım ve Çevre Koruma Bakanlığı, Gıda ve Tarım Örgütü (Food and Agriculture Organization-FAO) destekli ürün senetleri için elektronik kayıt sistemi geliştirmiştir (Jovicic vd., 2014: 350).

\section{ELÜS İhraç Aşamaları}

ELÜS'ler, Lisanslı Depo İșletmeleri tarafından düzenlenmekte olup, düzenleme aşamasında birden fazla paydaş görev alır.

ELÜS ihraç işleminin aşamaları ve paydaşları aşağıdaki Şekil 1'de gösterilmiştir.

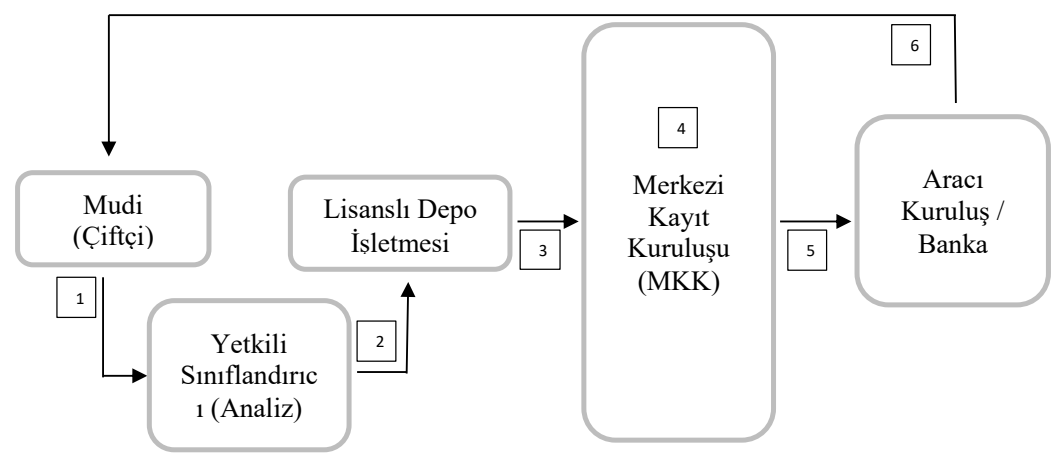

Şekil 1: ELÜS İhraç İşlemi Akış Diyagramı (MKK, 2017b)

İşlem süreçleri:

1. Mudi (çiftçi), ürettiği ürünü yetkili sinıflandırıcıya tarttırdıktan sonra teslim eder.

2. Yetkili Sinıflandırıcı ürünü analiz ederek, analiz bilgileri ile birlikte ürünü, Lisanslı Depo İsletmesi'ne gönderir.

3. Lisanslı Depo İşletmesi, ürünü depoladıktan sonra, ürün ve mudi ile ilgili bilgileri MKK'ya iletir.

4. Lisanslı Depo İşletmesi tarafindan ihraç işlemi gerçekleştirilen ELÜS, MKK'daki havuz hesabında kaydi olarak oluşturulur.

5. ELÜS, mudinin ürününü teslim aşamasında adını bildirmişs olduğu aracı kuruma veya aracı kurumun banka nezdindeki hesabina otomatik olarak aktarllır.

6. Mudinin mail adresine ve cep telefon numarasina, aracı kurum veya banka tarafindan işleme ait bilgi gönderilir. 


\section{ELÜS İhraç İşleminde Taraflar}

\section{a. Yetkili Sınıflandırıcılar}

5300 Sayılı Tarım Ürünleri Lisanslı Depoculuk Kanunu kapsamında depolanacak olan tarım ürünlerini analiz etmek, niteliklerini ve özelliklerini belirlemek, standartlara uygun olarak sınıflandırmak ve tüm bu özellikleri belgelendirmek, Yetkili Sınıflandırıcılar'ın görev alanı içerisindedir.

Yetkili Sınıflandırıcılar'ın yaptığı analizler, Lisanslı Depo İşletmeleri'ne yapılan ürünün teslimi, kabulü, muhafazası ve geri tesliminde tarafların hak kaybına uğramaması ve sisteme olan güvenin zedelenmemesi adına önem taşımaktadır. Bu sebeple, yılda en az iki defa Yetkili Sınıflandırıcılar'ın yaptıkları analizlerin doğruluğu ve gerçekliğinden emin olunması için, analiz cihazları yetkili kurumlar tarafından kontrol edilir (Yurtoğlu, 2015).

\section{b. Lisanslı Depo İşletmeleri}

Resmi Gazete'de yayınlanan 10 Ağustos 2017 tarihli yönetmeliğe göre; Lisanslı Depoculuk, tarım ürünlerinin depolanması ile iștigal eden ve 10/02/2015 tarih ve 5300 sayılı Tarım Ürünleri Lisanslı Depoculuk Kanunu kapsamında geçerli lisans bilgisine sahip anonim şirket olarak tanımlanmaktadır (Resmi Gazete, 2017, Sayl: 30150).

Ürün borsaları ile birlikte çalışan Lisanslı Depo İşletmeleri, tarımsal emtialara yönelik ticareti kolaylaştırmakta, tarımsal emtialar için yurtiçine dağılmış bir depolama sistemi oluşturabilmekte, ürününü teslim eden mudilere ürünün kalite ve emniyeti ile ilgili güvenilir bir koruma sağlayarak piyasasını genişletebilmekte, piyasada emtianın fiyat istikrarının oluşumuna yardımcı olmakta ve ekonomik sistemde kayıt dişı işlemlerin önlenmesinde etkili olmaktadır (Karabaş ve Gürler, 2010: 197).

Lisanslı Depo İşletmeleri;

- $\quad$ kendilerine teslim edilen ürünleri işletmelerine kabul etmekten,

- gerektiği durumlarda depolamaya uygun hale getirmekten,

- $\quad$ ürün kalite ve miktarını belirlemekten,

- ürünü sigorta ettirmekten,

- ürünü uygun şartlar altında depolamaktan,

- $\quad$ kabul edilen ürün karşılığında, ürünün sahibine borsada alıp satabileceği veya banka kredisi çekebilmek için teminat olarak bankasına verebileceği bir ürün senedi temin etmekten ve

- $\quad$ talep etmesi halinde ürün sahibine ürünü fiziksel olarak zamanında teslim etmekten sorumludurlar.

Lisanslı Depo İşletmeleri'nin faaliyet izni alabilmeleri için, kuruluş izni alan şirketin ilgili mevzuata göre lisans şartlarını taşıdığının tesbiti gerekir. Lisanslı Depoculuk faaliyetine başlayabilmek için Sanayi ve Ticaret Bakanlığı'ndan depoculuk lisansı alınması şarttır. Kuruluş izni alan Lisanslı Depo 
İşletmesi'nin, Ticaret Sicil Gazetesi'nde ilan ediliş̧inden sonraki bir yıl içerisinde faaliyet izni alması gereklidir (Mızrak, 2008).

\section{c. Merkezi Kayıt Kuruluşu (MKK)}

Merkezi Kayıt Kuruluşu, sermaye piyasası araçlarının kaydileștirilmesi ve kaydileștirilen bu araçlara bağlı hakların, elektronik bir ortamda üyeler ve hak sahipleri tarafindan izlenmesi ve merkezi olarak saklanması için 06/12/2012 tarihli 6362 sayll, SPK Kanunu hükümleri çerçevesinde kurulmuş bir resmi kurumdur. Merkezi Kayıt Kuruluşu, bir elektronik kayıt kuruluşu olarak, Lisanslı Depo İşletmeleri'ndeki tarım ürünlerini temsil eden Elektronik Ürün Senetlerinin elektronik ortamda oluşmasını sağlamak, ELÜS'lere bağlı hak ve yükümlülükleri güvence altına almak ve bunları kayden izlemek üzere Gümrük ve Ticaret Bakanlığı'nca yetkilendirilmiş bir kuruluştur (Yurtoğlu, 2015).

ELÜS'ler ve ELÜS'lere ilişkin haklarla alakalı kayıtlar, Merkezi Kayıt Sistemi içerisinde üyelerin nezdinde, mudiler adına açılmış olan hesaplarda izlenmektedir. Ürününü teslim edecek olan mudilerin, MKK üyesi bir aracı kuruluşta hesaplarının bulunması zorunludur (MKK, 2017a).

\section{Elektronik Ürün Senetlerinin Dayanak Varlık Olarak Kullanılabilmesi}

ELÜS'ün bir dayanak varlık olarak sukuk ihraçlarına konu edilip edilemeyeceği hususu önem arzetmektedir. Nelerin dayanak varlık olup olamayacağına Kira Sertifikalarına ve Varlık Kiralama Şirketlerine İlişkin Esaslar Hakkındaki Tebliğ'e göre karar verilebilir. Bu Tebliğ'de "varlık", "Varlık Kiralama Şirketi'nin satın alacağı veya kiralayacağı her türlü menkul veya gayrimenkul mallar ve maddi olmayan varlıklar" șeklinde tanımlanmıștır (Resmi Gazete, 2010, Sayı: 27359).

Elektronik Ürün Senedi Yönetmeliği'nde ise; ürün senedi, “lisanslı depolara teslim edilen tarım ürünleri karşllğ̆ında nama veya emre düzenlenen, ürünlerin mülkiyetini temsil ve rehnini temin eden, teminat olarak verilebilen, ciro edilebilen veya edilemeyen ve Kanun'da hüküm bulunmayan durumlarda Türk Ticaret Kanunu'nda düzenlenen makbuz senedi hükümlerine tabi olan matbu kıymetli evrak" olarak tanımlanmaktadır (Resmi Gazete, 2011). Menkul mal veya menkul değer ise taşınabilir nitelikte ekonomik kıymet ifade eden ve paraya çevrilmesi ya da parayla ifade edilmesi mümkün olan kıymetlere denir. Dolayısıyla, Elektronik Ürün Senetleri, kıymetli evrak olarak bir sukuk ihracında dayanak varlık olarak kullanılması mümkün olan bir kıymet olarak tanımlanabilir.

\section{Türkiye'de Tarım Ürünlerine Dayalı Olarak İhraç Edilmiş Sukuk Örnekleri}

Ülkemizde son yıllarda tarımsal emtiaların dayanak varlık olarak kullanılması yoluyla ihraç edilmiş sukuk ihraçları mevcuttur. Toprak Mahsulleri Ofisi ve 
TARKIM Bitki Koruma San ve Tic. A.Ş. adına ihraç edilen sukuk işlemlerinin detayları aşağıda verilmiştir.

Toprak Mahsulleri Ofisi, fon kullanıcısı ve kaynak kuruluş olarak tarihinde iki kez sukuk ihracı gerçekleştirmiştir. İlk olarak 27 Kasım 2017 tarihinde gerçekleştirilmiş olan ihraç, Hazine Müsteşarlığı'ndan sonra bir kamu kurumunun ilk ihracı olma niteliğini taşımaktadır. İhraç tutarı 100 Milyon TL. olup, ihraçta VKŞ olarak KT Sukuk Varlık Kiralama A.Ş. görev almıştır. İhracın vadesi 88 gündür. İhraç, kurumsal yatırımcılar ve nitelikli bireysel yatırımcılara yapılmıştır. İhracın vade başlangıç tarihi 27 Kasım 2017, yıllık basit getirisi $\% 12,95$ ve ylllık bileșik getirisi

\%13,60 oranındadır. Sukuk türü olarak Toprak Mahsulleri Ofisi ve KT Sukuk Varlık Kiralama A.Ş. arasında kurulan yönetim sözleşmesi ile alım satıma dayalı bir ihraç gerçekleşmiştir. İhraçta dayanak varlık olarak, Toprak Mahsulleri Ofisi'nin mülkiyetinde olan ve TMO depolarında tutulan Anadolu tipi kırmızı sert ekmeklik buğday kullanılmıștır (Halk Yatırım Basın Bülteni, 2017). Bu ihraç, Islamic Finance News (IFN) adlı derginin Ocak 2018 sayısında "Yllın İslami Finansman İşlemi Ödülleri" listesinde de yer almıştır.

TMO ikinci ihracını ise, 20 Temmuz 2018 tarihinde gerçekleştirmiştir. Bu ihraç 100 Milyon TL. tutarında ve 103 gün vadeli olup, ylllı basit getirisi \%18,50 ve yıllık bileșik getirisi \%19,76 oranında olmuştur. İlgili ihraca 17 farklı nitelikli yatırımcıdan 185 Milyon TL. lik talep gelmiştir.

TMO, ikinci ihracında dayanak varlık olarak buğday yerine kabuklu findık tercih etmiştir. Bu ihraç da ilk ihraç gibi yönetim sözleşmesine ve alım satıma dayalı olarak gerçekleştirilmiştir (TMO, 2018).

TMO'nun kaynak kuruluş olarak gerçekleştirdiği sukuk ihraçlarında süreç şu şekilde işlemiştir. İlk olarak Varlık Kiralama Şirketi, TMO'nun depolarındaki tarımsal emtiayı temsil eden makbuzları satın almak için sukuk ihraç etmiştir. İhraçtan elde edilen gelirle VKŞ, TMO'dan yatırımcıları adına tarımsal emtiayı satın almıştır. Sonrasında ise bu emtiayı TMO'ya belirlenen sukuk vadesine kadar satması için vekâlet vermiştir. TMO tarımsal emtianın satışını gerçekleştirdikten sonra elde ettiği geliri, kârı ile birlikte VKŞ aracılığıyla yatırımcılarla paylaşmıştır (Arzova ve Şahin, 2019: 10).

Tarım sektöründeki bir diğer sukuk ihracını ise 2020 yılı başında Kalkınma Yatırım Bankası'nın danışmanlığında gerçekleştirilmiştir. Bu ihraçla Tarım Kredi Kooperatifi iştiraki olan TARKIM Bitki Koruma San ve Tic. A.Ş.'ye 42 milyon TL. tutarında uzun vadeli kaynak sağlanmıştır. İhraçta VKŞ olarak ZKB Varlık Kiralama A.Ş. kullanılmıştır. Sukuk türü olarak ise yönetim 
sözleşmesine dayalı sukuk türü kullanılmıştır. Bu sukuk ihracı, Türkiye'deki tarım alanında gerçekleştirilen üçüncü sukuk ihracı olup, nitelikli yatırımcılara gerçekleștirilmiştir (TARKIM, 2020).

\section{Elektronik Ürün Senedine Dayalı Sukuk İhraç Süreçlerinin Modellemesi}

Elektronik Ürün Senedi kullanılarak farklı amaçlarla sukuk ihraç etmek mümkündür. Bu bölümde yönetim sözleşmesi ve alım satıma dayalı sukuk ihracl, yönetim sözleşmesi ve alım satıma (murabaha) dayalı sukuk ihracı, alım satıma (teverruk) dayalı sukuk ihracı ve ortaklığa (mudaraba) dayalı sukuk ihracı modelleri detaylandırılacak ve ayrıca bu dört farklı modelin avantajları, dezavantajları ve fikhi durumları hakkında bilgi verilecektir.

Model 1: Yönetim Sözleșmesi (Vakale) ve Alım Satıma Dayalı Hibrit Sukuk Modeli Yönetim sözleşmesi ve alım satıma dayalı bir sukuk modeli olan Model 1, iki farklı şekilde kurgulanabilir. Model 1a'da kaynak kuruluşun elinde ELÜS mevcut değildir. Bu sukuk ihraç yönteminde kaynak kuruluş, VKŞ’nin sukuk yatırımcılarından topladığı bedel ile VKȘ'ye vekâleten ELÜS satın alarak yatırım yapmaktadır. İhraçta sukuk yatırımcıları ilgili sukukların temsil ettiği varlıkların kârına veya zararına ortak olacaklardır. Bu sukuk modeli bir nevi vekâlete (vakala) dayalı sukuk şeklinde yapılandırılmıştır. Kaynak kuruluş, satın aldığı ELÜS'ler ile yatırım yapacak ve elde ettiği geliri sukuk yatırımcıları ile paylaşacaktır. Bu sukuk türünde kaynak kuruluş, sukuk yatırımcılarına sukuk ihraç aşamasında, "beklenen bir getiri" sözü verecektir. "Beklenen getiri" vekâlet işlemlerinde sözleşmede belirlenen ve yatırım vadesi sonunda vekâleti veren tarafa (yatırımcıya) ödenecek olan getiri miktarıdır. Vade sonunda beklenen getiri tutarının üzerinde bir gelir kazanılırsa beklenen getiri oranı kadar yatırımcılara ödeme yapılacak olup, kalan gelir vekilin olacaktır. Beklenen getiri altında bir gelir elde edilirse yatırımcllara bu gelirin tamamını ödeyecektir. Zarar durumunda ise yatırımcılara ana paralarından zarar eden kısım kadarını keserek ödeme yapılacaktır.

$\mathrm{Bu}$ ihraç modelinde yatırımcıların elindeki sukuklar, kaynak kuruluş tarafından ELÜS satın alındıktan satışı yapılıncaya dek ikincil piyasalarda işlem görebilirler. Çünkü bu durumda ilgili ELÜS'ler mevcut mal varlı̆ı̆ın temsil ederler. 
Aşağıdaki Şekil 2'de, Model 1a'ya ait işleyiş̧ şeması görülmektedir:

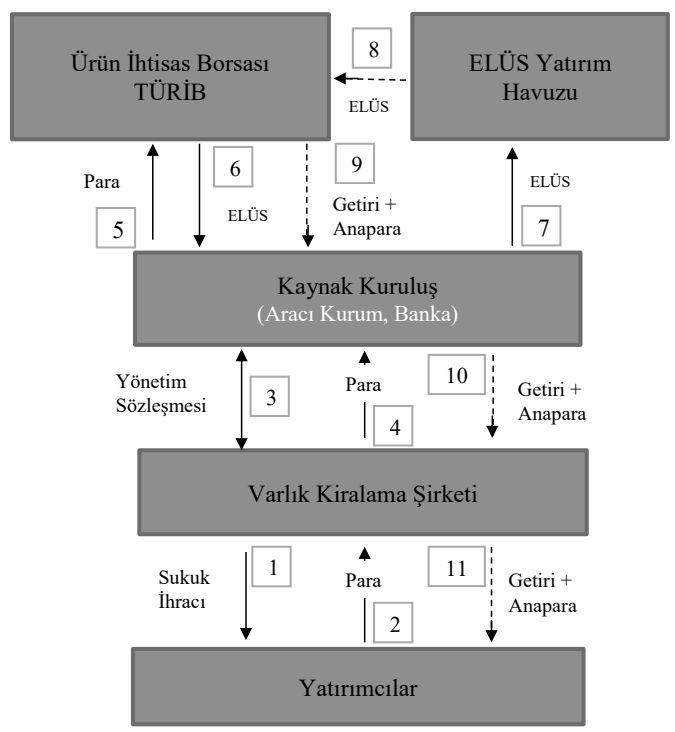

Şekil 2: (Model 1a) Yönetim Sözleșmesi (Vakale) ve Alım Satıma Dayalı Hibrit Sukuk Modeli

İşlem süreçleri:

1. VKŞ, kaynak kuruluş ile yaptığı sözleșmeye istinaden sukuk ihraç eder.

2. VKŞ, ihraç ettiği sukuk karşıllı̆ında yatırımcılardan sukuk bedellerini tahsil eder.

3. VKŞ, kaynak kuruluş ile yönetim sözleşmesi imzalar.

4. VKŞ, sukuk gelirleri ile bir ELÜS yatırım havuzu oluşturması için sukuk gelirlerini kaynak kuruluşa aktarır.

5. Kaynak kuruluş, Türkiye Ürün Ihtisas Borsası'ndan sukuk vadesine kadar gelir getirebilecek ELÜS'leri satın almak için ELÜS bedelini öder.

6. TÜRIB, ELÜS'lerin mülkiyetini MKK nezdinde kaynak kuruluşa devreder.

7. Kaynak kuruluş satın aldığı ELÜS'ler ile bir yatırım havuzu oluşturur.

8. Sukuk vadesine kadar yatırım havuzundaki ELÜS'leri TÜRIB'de satar.

9. Kaynak kuruluş, yönetim sözleșmesinde beklenen getiri oranının üzerinde gelir elde ederse fazlalık olan gelir, kaynak kuruluşun olur. Beklenen getiri oranı kadarlık kârı VKŞ'ye devreder. Beklenen getiri oranı altında kâr elde ederse bu kârın tamamını VKŞ'ye aktarır. Zarar ederse ana paradan bu tutarı düşerek VKŞ’ye ödeme yapar.

10. VKȘ, itfa tarihinde ana para + (varsa) kârı yatırımcılara öder. 
Așağıdaki Şekil 3'de görülen Model 1b'de ise; kaynak kuruluş aynı zamanda fon kullanıcısı olmakta ve sahipliğindeki mevcut ELÜS'lerin mülkiyetini VKŞ aracılığıyla yatırımcılara devretmektedir. VKŞ'den aldığı satış vekaletine istinaden ELÜS'leri itfa tarihine kadar piyasada paraya çevirmekte ve elde ettiği geliri yatırımcllarla paylaşmaktadır.

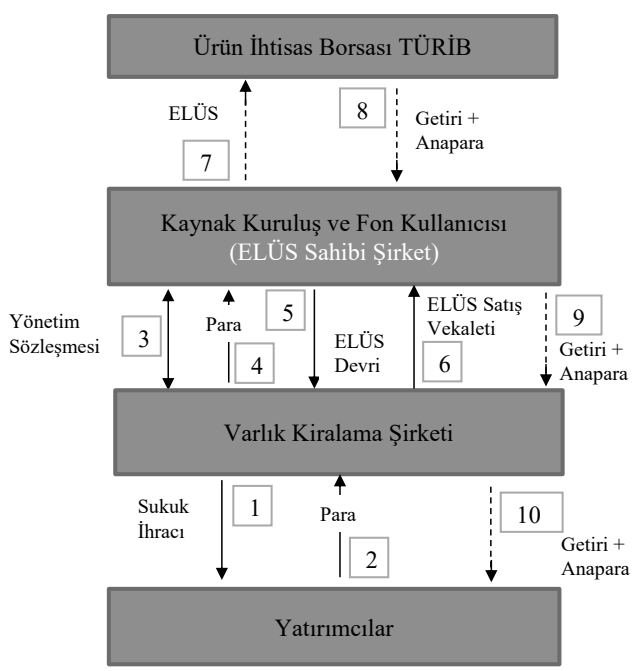

Şekil 3: (Model 1b) Yönetim Sözleşmesi (Vekalet) ve Alım Satıma Dayalı Hibrit Sukuk Modeli

İşlem süreçleri:

1. VKŞ, kaynak kuruluş ile yaptı̆̆ı sözleşmeye istinaden sukuk ihraç eder.

2. VKŞ, ihraç ettiği sukuk karşıliğında yatırımcılardan sukuk bedellerini tahsil eder.

3. VKŞ, kaynak kuruluş ile yönetim sözleşmesi imzalar.

4. VKŞ, kaynak kuruluşun elindeki ELÜS'leri satın almak için parayı kaynak kuruluşa aktarır.

5. Kaynak kuruluş ELÜS'leri MKK aracıliğıyla VKŞ̧'ye devreder.

6. VKȘ, ELÜS'leri kendi adına satması için Kaynak Kuruluş'a vekalet verir.

7. Kaynak kuruluş satın aldı̆̆ı ELÜS'leri itfa tarihinden önce TÜRIB'de satar.

8. Kaynak kuruluş satışstan getiri elde eder.

9. Kaynak kuruluş, yönetim sözleşmesinde beklenen getiri oranının üzerinde gelir elde ederse fazlalık olan gelir, kaynak kuruluşun olur. Beklenen getiri oranı kadarlık bedeli VKŞ'ye devreder. Beklenen getiri oranı altında kâr elde ederse bu kârın tamamını VKŞ'ye aktarır. Zarar ederse ana paradan bu tutarı düşerek VKŞ'ye ödeme yapar.

10.VKS, itfa tarihinde ana para + (varsa) kârı yatırımcllara öder. 


\section{Yönetim Sözleşmesi ve Alım Satıma Dayalı Sukuk Modelinin Avantaj ve Dezavantajları Avantajları:}

- $\quad$ Bu sukuk yapısı varlığa dayalı (asset backed) sukukyapısındadır.

- Bu sukukyapısında dayanak varlıktan kaynaklı kâr ve zarar riski yatırımcı ile paylaşıldığından değişken getiri sağlarlar. Bu nedenle temerrüt riski taşımazlar.

- Dayanak varlıkların kaynak kuruluş tarafından gerçek alım satımı ile VKŞ'ye devredilmeleri bu yapının bir özelliğidir.

- $\quad$ Sukukyatırımcıları dayanak varlığın VKȘ üzerinden kendilerine devredilmesi sayesinde tam anlamıyla varlığa malik olurlar.

- Yatırımclar sahip oldukları sukukları ELÜS'lerin kaynak kuruluş tarafindan satışına kadar ikincil piyasada devretme hakkına sahiptirler.

- Kaynak kuruluş, ELÜS'e dönüşebilen her türlü tarımsal emtiayı dayanak varlık olarak kullanma şansına sahiptir.

- $\quad$ ELÜS'e dayalı ihraç edilen sukuklar, faizsiz BES ve yatırım fonlarında sigorta şirketleri ve portföy yönetim şirketleri tarafindan yatırım amacıyla da kullanılabilirler.

\section{Dezavantajları:}

- Değişken getirili sukuklar olduklarından, yatırımcılar bekledikleri kârı alamama ya da zarar etme riskine sahiptirler.

- Kaynak kuruluş belirlenen vadeye kadar elindeki emtiayı satacak müşteri bulamama riskine sahiptir (Arzova ve Şahin, 2019: 10).

- Kaynak kuruluş elindeki emtiayı başta belirlenen getiri oranı altında sattığı durumda işlemin etkinliği azalacaktır (Arzova ve Şahin, 2019: 10).

- $\quad$ Satışa kadar geçecek olan sürede Lisanslı Depo İsletmeleri'ne depolama ücreti ödenecektir.

- $\quad$ Satın alınacak ELÜS'lerin son depolama tarihlerinin sukuk vadesi ile aynı veya daha uzun olması gerekmektedir.

\section{Model 2: Yönetim Sözleşmesi ve Alım Satıma (Murabaha) Dayalı Hibrit Sukuk Modeli}

Bu sukuk modeli, kaynak kuruluş olarak katılım bankalarının finansman ihtiyaçlarını karşılamak için kullanabilecekleri bir modeldir. Bu yapıda ELÜS, dayanak varlık olarak kullanılacaktır. Bu yapıda kaynak kuruluş, VKŞ ile yönetim sözleşmesi yaparak VKŞ’ye vekâleten murabaha yöntemi ile VKȘ’nin sukuk yatırımcılarından topladığı meblağ ile peșin olarak ELÜS satın alacak ve vadeli olarak ürüne ihtiyacı olan üçüncü tarafa satarak gelir elde edecek ve elde ettiği geliri sukuk yatırımcılarına dağıtacaktır.

$\mathrm{Bu}$ ihraç modeli murabaha sözleşmesine dayalı olarak gerçekleştirildiğinden ihraç edilen sukuklar, murabahaya konu olan ELÜS'ler üçüncü tarafa satılıp teslim edildikten sonra ikincil piyasada işlem göremezler. Çünkü bu durumda 
sukuk, ELÜS'ü değil, üçüncü tarafın borcunu temsil etmektedir. Aksi halde bu sukuklar fıkıhtaki, borcun satışı hükmüne göre değerlendirilmekte ve ikincil piyasada alım satıma uygun bulunmamaktadırlar. Fakat ELÜS'ler kaynak kuruluş tarafından satın alınıp henüz üçüncü tarafa satılmadan önce sukuklar, mevcut mal varlığını temsil ettiği için, ikincil piyasalarda işlem görebilirler.

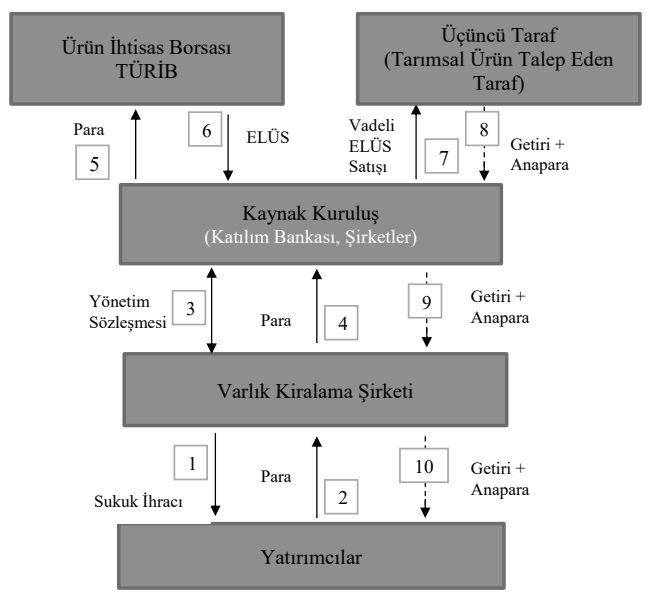

Şekil 4: Yönetim Sözleşmesi ve Alım Satıma (Murabaha) Dayalı Hibrit Sukuk Modeli İşlem süreçleri:

1. VKŞ, kaynak kuruluş ile yaptı̆̆ı sözleşmeye istinaden sukuk ihraç eder.

2. VKȘ, ihraç ettiği sukuk karşılığında yatırımcılardan sukuk bedelini tahsil eder.

3. VKŞ, kaynak kuruluş ile yönetim sözleșmesi imzalar.

4. VKȘ, sukuk gelirleri ile peşin olarak ELÜS satın alması ve vadeli olarak piyasada satması için sukuk bedelini kaynak kuruluşa aktarır.

5. Kaynak kuruluş Ürün İhtisas Borsası'ndan ELÜSleri satın almak için bedel öder.

6. TÜRIB, ELÜS'lerin mülkiyetini MKK'da kaynak kuruluşa devreder.

7. Kaynak kuruluş peşin olarak satın aldı̆̆ı ELÜS'leri, murabaha sözleşmesi yaptığı üçüncü tarafa (sukuk vadesi ile aynı olmak şartılla) vadeli olarak satar. Satış sonrası ELÜS sahipliği MKK nezdinde üçüncü tarafa devredilir. Üçüncü taraf ELÜS'ün temsil ettiği ürüne ihtiyaç duyuyorsa Lisanslı Depo'dan ürününü teslim alır, finansmana ihtiyaç duyuyorsa TÜRIB'de ELÜS'ü satarak fon ihtiyacını giderebilir.

8. Kaynak kuruluş, sukuk vadesinde üçüncü taraftan alacığını tahsil eder.

9. Kaynak kuruluş, ihraç öncesinde belirlenen getiri oranında elde ettiği kârı ve ana parayı VKŞ'ye aktarır.

10. VKŞ, sukuk vadesinde (itfa tarihinde) ana para + kârı yatırımcılara öder. 


\section{Yönetim Sözleşmesi ve Alım Satıma Dayalı (Murabaha) Hibrit Sukuk Modeli Avantaj ve Dezavantajları Avantajları:}

- $\quad$ Bu sukuk yapısı varlık temelli (asset backed) sukuk yapısındadır.

- $\quad$ Sabit getirili sukuklardır.

- $\quad$ Kaynak kuruluş, ELÜS'e dönüşebilen her türlü tarımsal emtiayı dayanak varlık olarak kullanma şansına sahiptir.

\section{Dezavantajları:}

- İhraç modeli, murabaha sözleșmesine dayalı olarak gerçekleștirildiğinden ihraç edilen sukuklar, murabahaya konu olan ELÜS'ler üçüncü tarafa satılıp teslim edildikten sonra ikincil piyasalarda işlem göremezler.

- $\quad$ Sabit getiri kazandirmaları nedeniyle bu yapı fikhen uygun bir sukuk ihracı sayılmayabilir.

\section{Model 3: Alım Satıma (Teverruk/Emtia Murabahası) Dayalı Sukuk Modeli}

Bu sukuk modeli, finansman ihtiyacı olan bir katılım bankası (kaynak kuruluş) tarafından kullanılabilir. Ülkemizde özellikle katılım bankaları finansman ihtiyaçlarını gidermek için bu yöntemi kullanmaktadırlar. Fakat fıkhi danışma kurulları bu sukuk türünü hibrit sukuk yapısı içerisinde \%49 oranını geçmeyecek şekilde kullanmaları durumunda katılım bankalarına izin vermektedirler. Bu nedenle kalan \%51'lik kısım genellikle yönetim sözleşmesi veya icare sukuk yapısında gerçekleştirilmektedir.

Emtia murabahası (commodity murabahah) sukuk veya teverruk sukuk adıyla da anılabilecek olan bu sukuk modeli, SPK mevzuatına göre alım satıma dayalı sukuk türü içerisinde sınıflandırılabilir.

Günümüzde katılım bankaları alım satıma dayalı sukuk ihraçlarında, emtia alım satımı yapmak için Londra Metal Borsası'nı (LME) kullanmaktadırlar. Bu Borsa'da genellikle emtia olarak platin veya paladyum gibi değerli metaller, aracı brokerlar tarafından alınıp satılmaktadır. Fakat bu Borsa'da gerçekleştirilen işlemler LME'nin yapısı gereği fıkhen uygun bulunmamaktadır. Kazancı (2018)'nın, “Türkiye'de Faizsiz Bankacılık Prensiplerine Uygun Teverruk Pazarı: Ürün İhtisas Borsası" adlı makalesine göre; kurulacak olan Ürün İhtisas Borsası, Londra Metal Borsası'na alternatif olarak Türkiye'de katılım bankacılığı prensiplerine uygun bir teverruk piyasası oluşturabilecektir (KazanCl, 2018: 45). Bu modelde önerilen sukuk ihraç işleminin emtia alım satım işlemleri, 2018 yılı haziran ayında kurulan Türkiye Ürün İhtisas Borsası'nın (TÜRİB) 2022 yılı ortalarında kurmayı planladığı TÜRİB Teverruk Piyasası aracılığıyla gerçekleştirilebilecektir.

Alım satıma dayalı model, hibrit yapı içerisinde \%49 luk bir oranı kapsadığından bu sukuk ihraçlarının ikincil piyasada işlem görmesi ancak \%51'lik sukuk yapısının ikincil piyasaya uygun olmasına bağlıdır. 
Așağıdaki Şekil 5'te alım satıma dayalı sukuk modelinin işleyiş şeması gösterilmektedir.

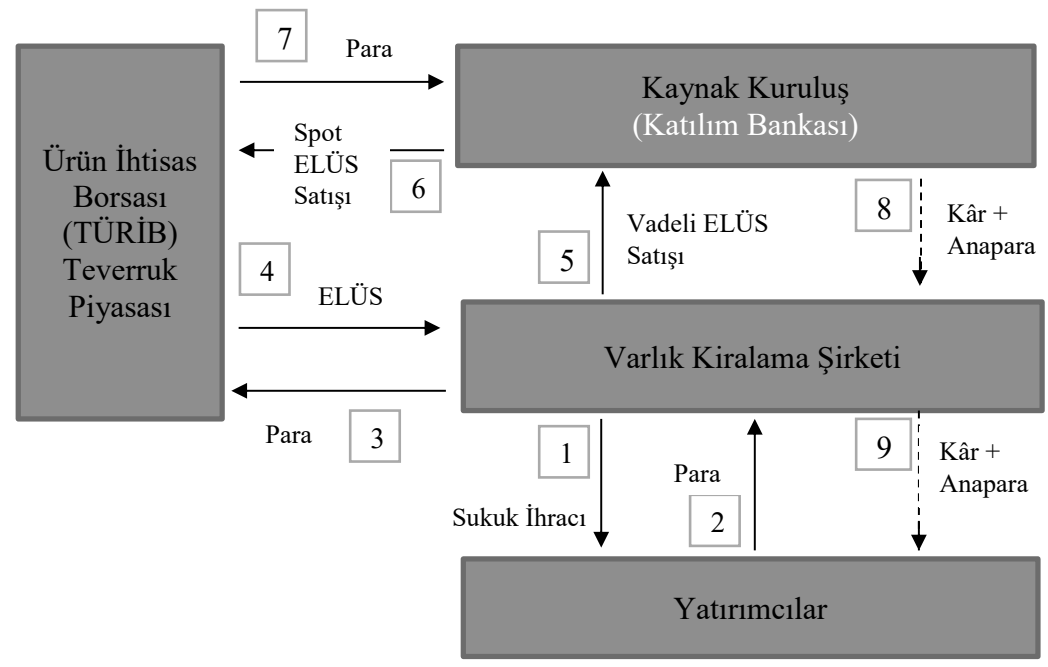

Şekil 5: Alım Satıma (Teverruk/Emtia Murabahası) Dayalı Sukuk Modeli

İşlem süreçleri:

1. VKŞ, kaynak kuruluş ile yaptı̆ı̆ sözleşmeye istinaden sukuk ihraç eder.

2. VKŞ, ihraç ettiği sukuk karşılığında yatırımcılardan sukuk bedelini tahsil eder.

3. VKȘ, Ürün Ihtisas Borsası (TÜRIB) Teverruk Piyasası'ndan ELÜS satın almak için bedeli öder.

4. TÜRIB ELÜS'ü VKŞ'nin mülkiyetine geçirir.

5. VKŞ, satın aldı̆̆ı ELÜS'ü sukuk vadesi ile aynı güne denk gelecek șekilde vadeli olarak kârı ile birlikte kaynak kuruluşa satar. ELÜS sahipliği TÜRIB'de kaynak kuruluşa devredilir.

6. Kaynak kuruluş ELÜS'ü TÜRiB'de aynı gün içerisinde satar.

7. TÜRIB, ELÜS bedelini kaynak kuruluşa aktarır.

8. Kaynak kuruluş sukuk vadesinde VKŞ'ye anapara ve kârl öder.

9. VKŞ yatırımcılara anapara ve kârı öder.

\section{Alım Satıma Dayalı (Teverruk) Sukuk Modeli Avantaj ve Dezavantajları Avantajları:}

- $\quad$ Bu sukuk yapısi varlık temelli (asset backed) sukuk yapısindadır.

- Katılım bankaları için pratik bir finansmana ulaşma yöntemidir.

- $\quad$ Sabit getirili sukuklardır. 


\section{Dezavantajları:}

- Bu sukukyapısında yatırımcılara yapılacak ödemelerin kaynağı dayanak varlık değil, kaynak kuruluşun nakit akımıdır. Bu nedenle bu sukuklar temerrüt riski taşırlar.

- Ihracın tamamı teverruk sözleşmesine dayalı olarak gerçekleştirilirse, ihraç edilen sukuklar ikincil piyasalarda ișlem göremezler. Teverruk sözleșmesine dayalı bu model, hibrit yapı içerisinde \% 49 luk bir oranı kapsadı̆̆ı zaman bu sukuk ihraçlarının ikincil piyasada işlem görmesi ancak \%51'lik sukuk yapısının ikilcil piyasaya uygun olup olmamasına bağlı olacaktır.

- $\quad$ Sabit getiri getirmeleri nedeniyle bu model, fikhen uygun bir sukuk ihracı sayılmayabilir.

\section{Model 4: Ortaklığa (Mudaraba) Dayalı Sukuk Modeli}

Bu modelde ELÜS kullanılarak bir imalatçı ile VKŞ’nin mudaraba yani emek sermaye ortaklığı kurarak sukuk ihraç etmesi modellenmiştir. Modele göre VKŞ, tarımsal hammadde ihtiyacı olan imalatçıya sermaye olarak ELÜS satın alıp teslim edecek, imalatçı da emeğini ortaya koyarak üretim yapacak ve elde ettiği kârı bașta VKŞ ile anlaştığı orana göre VKŞ ile paylaşacaktır. Varlığa dayalı bir model olan bu yapıda sukuklar ikinci el piyasada alınıp satılabilir.

Aşağıdaki Şekil 6’da ortaklığa (mudaraba) dayalı sukuk ihraç modeli görülmektedir.

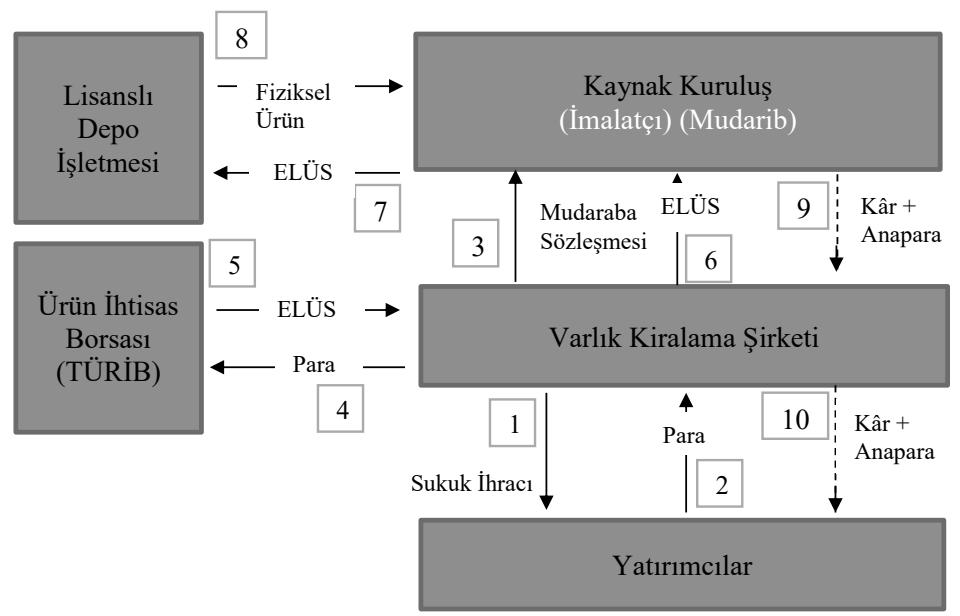

Şekil 6: Ortaklığa (Mudaraba) Dayalı Sukuk Modeli 


\section{İşlem süreçleri:}

1. VKȘ, kaynak kuruluş ile yaptığı sözleşmeye istinaden sukuk ihraç eder.

2. VKŞ, ihraç ettiği sukuk karşılığında yatırımcılardan sukuk bedellerini tahsil eder.

3. Kaynak kuruluş, VKŞ ile mudaraba sözleșmesi imzalar. Bu sözleşmede kâr paylaşım oranı belirlenir

4. VKŞ, TÜRIB'den ELÜS satın almak için bedeli öder.

5. TÜRIB, ELÜS'ü MKK nezdinde VKŞ'nin mülkiyetine geçirir.

6. VKŞ, satın aldığı ELÜS'ü kaynak kuruluşa MKK'da devir yaparak teslim eder. Böylece kaynak kuruluşa sermaye temin etmiş olur.

7. Kaynak kuruluş fiziksel ürün ihtiyacı için Lisanslı Depo İşletmesi'nden ürününü teslim almak için başvurur.

8. Lisanslı Depo İşletmesi fiziksel ürünü kaynak kuruluşa teslim eder.

9. Kaynak kuruluş olan imalatçı, ürünü işleyerek mamûl hale getirip piyasada satarak kâr elde eder. Mudaraba sözleșmesinde belirlenen kâr paylașım oranına göre kârı VKŞ ile paylaşır. Anapara ile birlikte kârı VKŞ'ye transfer eder.

10. VKŞ yatırımcılara anapara ve kârı öder.

\section{Ortaklığa (Mudaraba) Dayalı Sukuk Modeli Avantaj ve Dezavantajları Avantajları:}

- $\quad$ Tarımsal hammadde kullanarak gıda üretimi yapan firmalar için pratik bir finansmana

ulaşma yöntemidir.

- $\quad$ Ikinci el piyasada alım satıma uygun bir sukuk ihracıdır.

- $\quad$ ELÜS'e dayalı ihraç edilen sukuklar faizsiz BES ve yatırım fonlarında sigorta şirketleri ve portföy yönetim şirketleri tarafından yatırım amacıyla da kullanılabilirler.

\section{Dezavantajları:}

- Sukukyatırımcilarının koydukları sermayenin geri ödenmesi garanti edilmez.

- Kâr sabit olmadığı ve zarar riski mevcut olduğundan bazı yatırımcılar için tercih sebebi olmayabilir.

\section{Modellerin Fıkhi Açıdan Değerlendirilmesi}

Sukuklardan elde edilecek olan ihraç gelirinin, fikhi açıdan onaylanan herhangi bir meşru sözleşmeye dayalı olarak işletilmesi veya yatırımda kullanması durumunda sukuk ihracı caiz görülmektedir.

Murabaha sözleşmesine dayalı olarak sukuk ihraç eden taraf, murabaha sözleşmesine konu olan malın satıcısı, yatırımcılar da bu malın alıcısı konumundadırlar. İhraçtan elde edilen gelir bu malın satış bedelidir. İhracın sonunda sukuk satın alan yatırımcılar, menkulleştirilmek suretiyle satılan bu malın 
sahibi olurlar. Böylece ilgili mal satıldığı zaman, bu malın satılan bedelini de hak ederler.

Mudaraba ortaklığına dayalı sukuk ihraç eden taraf, ortaklıkta emek sahibi olan mudaribi temsil ederken, yatırımcılar sermaye sahibini (rabbü'l-mâl) temsil eden taraftır. İhraç geliri ilgili ortaklığın sermayesidir. Bu yöntemle ihraç edilen sukuku alan yatırımcılar, ilgili ortaklığın varlıklarına ve başta belirlenen orandaki kârına da sahip olurlar. Ortaklığın zarar etmesi halinde zarara, sermaye sahibi olan yatırımcllar katlanmak zorundadırlar.

Yatırım vekâletine dayalı olarak sukuk ihraç eden taraf, yatırımda kullanılacak olan fonu yönetecek olan yatırım vekili konumundadır. Yatırımcılar da müvekkil konumuna sahiplerdir.İhraç geliri, vekâlet yöntemi ile işletilecek olan fondur. Vekâlet yöntemiyle ihraç edilen sukuku alan yatırımcılar, ilgili sukukun temsil ettiği varlıklara gelir ve giderleriyle sahip olurlar. Bu yöntemde yatırımcılar birbirlerinin ortakları olduklarından, kâr gerçekleşirse kârın da sahibi olurlar.

Sukukların ikincil piyasada alım satımları ise sukuk ihracında kullanılan sözleșmelere göre değişiklik göstermektedir. Mevcut mal, menfaat ya da hizmet şeklindeki varlıklara dayalı hisse ile sahip olmayı simgeleyen sukukların, ikincil piyasalarda işlem görmesi fikhen uygundur. Bu durum ihraç tamamlandıktan, sukuk ihraç edildiği amaç için yatırımcılara tahsis edildikten ve sukukla ilgili yatırım faaliyeti başladıktan sonra geçerlidir.

Fıkhi ilkelere aykırı olmadığı ve hamiline düzenlendikleri sürece sukukların hesaba kaydedilmesi, elektronik ortamda işlem yapılması ya da fiziken teslim edilmesi gibi yöntemlerle ikincil piyasalar da alınıp satılması caizdir. Aynı caiziyet durumu ELÜS'ler için de geçerlidir.

Murabaha sözleşmesine dayalı ihraç edilen sukukların, murabahaya konu olan malın müşteriye teslim edilme sonrasında ikincil piyasada işlem görmesi fikhi açıdan uygun değildir. Fakat bu çeşit sukuklar, ilgili mal alınıp henüz müşteriye satılmadan, yani vadeli satışı gerçekleşmeden önce ikincil piyasalarda işlem görebilirler. Mudaraba ve vekâlet sözleşmelerine istinaden ihraç edilen sukuklar; ihraç gerçekleştikten, sukuklar ihraç amacına uygun bir şekilde yatırımclara tahsis edildikten ve yatırım faaliyeti ilgili mallar veya menfaatler için başladıktan sonra ikincil piyasalarda fikhi açıdan işlem görebilirler (AAOIFI, 2010: 375-385).

Mudaraba ve murabaha sözleşmeleri mal satımına dayalı olarak yapılmaktadır. Faiz yasağı ihlal edilmedikçe ve bu akitler için fikhi kurallar çiğnenmedikçe bu tür sözleşmelere dayalı olarak ihraç edilen sukuklar caizdir. Borç satımına dayalı sukuk yapısı ise, fıkıh kurallarına göre borcun satımı ile ilgili kurallara aykırı unsurlar taşıdığı için caiz görülmez (Bayındır, 2015: 118). 


\section{Genel Değerlendirme}

Aşağıdaki Tablo 3'te modeller genel özelliklerine göre özetlenmiştir. Önerilen sukuk modellerinin ilki yönetim sözleşmesi (vekâlet) ve alım satıma dayalı hibrit bir model olup, varlığa dayalı, ikincil piyasada alınıp satılabilen, değişken getirili, temerrüt riski taşımayan ve fıkhi açıdan uygun bir modeldir. Fakat değişken getirili olması nedeniyle zarar riski taşımaktadır. İkinci model ise yönetim sözleşmesi ve alım satıma (murabaha) dayalı olup, varlık temelli, ikincil piyasası olmayan, sabit getirili ve fıkhi açıdan tartışmalı bir yapı olduğu halde sabit getiri sağlaması sebebiyle yatırımcılar tarafindan tercih edilebilir. Üçüncü model ise, alım satıma (teverruk/emtia murabahası) dayalı olup, katılım bankaları tarafından operasyonel basitliği, operasyonel hızı ve yurtdışındaki bir emtia borsası yerine ülkemizdeki fıkhi açıdan uygun bir emtia borsasındaki teverruk piyasasında işlem yapılarak ihraç edilecek olması sebebiyle tercih edilebilecek fakat ikinci modelde bahsedilen olumsuzlukları da içeren bir modeldir. Dördüncü model ise ortaklığa (mudaraba) dayalı olup, değişken getirili, ikincil piyasada alınıp satılabilen ve fıkhi açıdan uygun bir modeldir.

Tablo 3: Makalede Önerilen Sukuk İhraç Modellerinin Genel Özellikleri

\begin{tabular}{|c|c|c|c|c|}
\hline & Model 1 & Model 2 & Model 3 & Model 4 \\
\hline Sukuk Türü & $\begin{array}{c}\text { Yönetim } \\
\text { Sözleşmesi } \\
\text { (Vakale) ve Alım } \\
\text { Satıma Dayalı }\end{array}$ & $\begin{array}{c}\text { Yönetim } \\
\text { Sözleşmesi ve } \\
\text { Alım Satıma } \\
\text { (Murabaha) } \\
\text { Dayalı }\end{array}$ & $\begin{array}{c}\text { Alım Satıma } \\
\text { (Teverruk/Emtia } \\
\text { Murabahası) } \\
\text { Dayalı }\end{array}$ & $\begin{array}{c}\text { Ortaklığa } \\
\text { (Mudaraba) } \\
\text { Dayalı }\end{array}$ \\
\hline $\begin{array}{l}\text { Dayanak Varlığın } \\
\text { Özelliği }\end{array}$ & Varlığa Dayalı & Varlık Temelli & Varlık Temelli & Varlığa Dayalı \\
\hline Fon Kullanıcısı & $\begin{array}{l}\text { Katılım } \\
\text { Bankaları, } \\
\text { Şirketler }\end{array}$ & $\begin{array}{c}\text { Katılım } \\
\text { Bankaları, } \\
\text { Şirketler }\end{array}$ & $\begin{array}{l}\text { Katılım } \\
\text { Bankaları }\end{array}$ & Şirketler \\
\hline Kaynak Kuruluş & $\begin{array}{c}\text { Aracı Kurumlar, } \\
\text { Katılım } \\
\text { Bankaları } \\
\end{array}$ & \begin{tabular}{|c|} 
Aracı Kurumlar, \\
Katılım \\
Bankaları \\
\end{tabular} & $\begin{array}{l}\text { Katılım } \\
\text { Bankaları }\end{array}$ & Şirketler \\
\hline İkincil Piyasası & Var & Yok & Yok & Var \\
\hline Getirisi & Değişken & Sabit & Sabit & Değişken \\
\hline Fıkhi Uyumu & Uygun & Tartışmalı & Tartışmalı & Uygun \\
\hline $\begin{array}{l}\text { Lisanslı } \\
\text { Depolama } \\
\text { Maliyeti }\end{array}$ & Var & Yok & Yok & $\begin{array}{c}\text { Ürün teslim } \\
\text { alınıncaya kadar } \\
\text { var }\end{array}$ \\
\hline $\begin{array}{l}\text { Dayanak Varlığın } \\
\text { Mülkiyetinin } \\
\text { Devri }\end{array}$ & Var & Yok & Yok & Var \\
\hline
\end{tabular}




\section{Sonuç}

Elektronik Ürün Senetleri son yıllarda ülkemizde de kullanılmaya başlanmış olup, ELÜS hacmi her geçen yıl daha da artmakta ve Türkiye Ürün İhtisas Borsası'nda alınıp satılabilmektedirler. Üreticilere ve ülkenin tarımsal gelişimine katkı sağlayan ELÜS'ler, sukuk ihraçlarında da kullanılacak nitelikte bir dayanak varlıktır.

Bu makalede ELÜS'ler dayanak varlık olarak kullanılarak dört farklı sukuk yapısı modellenmiştir. Önerilen sukuk modelleri, SPK Tebliği'ndeki sukuk çeşitlerine göre yönetim sözleşmesine, alım satım sözleşmesine ve ortaklığa dayalı modellerdir.

Dayanak varlık olarak Elektronik Ürün Senetleri kullanılarak sukuk ihraçlarının yapılacak olması sonucunda;

ㅁ Daha fazla tarım ürünü ELÜS'e çevrilecek ve piyasada dolaşan ELÜS hacmi artacaktır.

Böylece tarım sektörü daha fazla desteklenecektir.

$\quad$ Elinde tarımsal emtiayı temsil eden ELÜS bulunduran üreticiler, komisyoncular, aracılar, kooperatifler ve kurumlar finanse edilebilecektir.

ㅁ Hammadde bedelini ödemekte zorlanan işlenmiş gıda üreticileri mudaraba sukuk yapısı sayesinde üretimini artırabilecektir.

口 Sukukyatırımcıları faizsiz bir yatırım aracı ile ikincil piyasalarda alım satım yaparak kâr elde edebileceklerdir.

ㅁ Katılım bankaları ELÜS'ü dayanak varlık olarak kullanarak sukuk ihraç çeșitlerini artırabilecek ve fikhi açıdan daha uygun bir şekilde finansmana ulaşabileceklerdir.

Ülkemizde Elektronik Ürün Senetleri'nin dayanak varlık olarak kullanılması ile katılım bankacılığına, çiftçilere, gıda üreticilerine, komisyonculara, aracılara ve kooperatiflere finansman inkânı sağlanacaktır. Böylece sukuk yatırımcıları da yaptıkları bu yatırımları sayesinde bu sektörlere destek verecekler ve faizsiz kazanç elde edebileceklerdir.

Dünya geneline yayılan tarımsal faaliyetlerin yoğun olduğu diğer İslam ülkelerinde de ürün senetlerinin kullanılmaya başlanması ve yaygınlaşmasıyla birlikte, kâğıt veya elektronik ortamda üretilen ürün senetlerinin dayanak varlık olarak kullanılarak sukuk ihraçlarının yapılması mümkün olacak ve böylece bu üllkelerde de İslami bankacılığın ve ziraatin gelişimine katkıda bulunulması imkânı elde edilebilecektir. 


\section{Kaynakça}

AAOIFI (2010). el-Meâyirü’ş-şeriyye. Manama. Türkçe çevirisi: Faizsiz Bankacılık Standartları. Türkiye Katılım Bankaları Birliği, Yayın No: 2. İstanbul: 2012.

Aktaş, M.M. (2016). Ortaklığa dayalı İslâmî yapılandırılmış finansman ürünü: muşaraka sukuk. Dumlupınar Üniversitesi Sosyal Bilimler Dergisi. Afro-Avrasya Özel Sayısı-Aralık 2016.

Anisa, D. \& Santoso, R. (2020). The role of Islamic bonds (sukuk) toward Indonesia economy. Journal of Islamic Business and Economic Review (JIBER), 3(1), 43-48.

Arzova, S.B. \& Şahin, B.Ş. (2019). Tarımda kira sertifikalarının (sukuk) kullanımı, muhasebeleștirilmesi ve hukuki boyutu. Journal of Accounting \& Finance, (83).

Bayındır, S. (2015). Fıkhi ve iktisadi açıdan İslami finans (para ve sermaye piyasaları). Süleymaniye Vakfı Yayınları. Yayın No: 21.

Beik, I. S. \& Hafidhuddin, D. (2008). Enhancing the role of sukuk on agriculture sector financing in Indonesia: proposed models. Islamic Capital Markets, 85.

Cebeci, İ. (2016). Sukuk. TDV İslam ansiklopedisi, Cilt Ek 2, Sh. 529-533.

Çelimli, S. ve Adanacıoğlu, H. (2016). Tarım ürünleri ticaretinde Elektronik Ürün Senedi uygulaması: pamuk örneği. Conference Paper. 12. Ulusal Tarım Ekonomisi Kongresi. Mayıs 2016.

Gashayie, A. \& Singh, M. (2015). Agricultural finance constraints and innovative models experience for Ethiopia: Empirical evidence from developing countries. Research Journal of Finance and Accounting, 6(7), 39-49.

Gümrük ve Ticaret Bakanlığg (2017). "Lisanslı depoculuk sisteminde ürün senedi”, Ticaret_Bakanligi_Dursun_Coskuncelebi-U run_Senedi_Karsiligi_Finansman_Programi.pdf 12.05.2020.

Gün, N. ve Tahsin, E. (2019). Role of Electronic Warehouse Receipt system in development of commodity exchanges: an assessment for Turkey. Tarım Ekonomisi Araştırmaları Dergisi, 5(1), 9-24.

Hollinger, F. \& Rutten, L. (2009). The use of Warehouse Receipt finance in agriculture in ECA countries, FAO World Bank Cooperative Programme/ FAO EBRD Cooperative Programme. In World Grain Forum (p. 50).

İSEDAK (2019). İslami sermaye piyasalarında sukukun rolü. İSEDAK Koordinasyon Ofisi. Haziran 2019.

Jovicic, D., Jeremic, L., Milicevic, L., \& Zeremski, A. (2014). Warehouse receipts functioning to reduce market risk. https://cyberleninka.ru/article/n/warehouse-receipts-functioning-to-reduce-market-risk 26.01.2021.

Karabaș, S. ve Gürler, A.Z. (2010). Lisanslı depoculuk sisteminin işleyişi ve Türkiye'de uygulanabilirliği. Sosyal Bilimler Araștırmaları Dergisi, (1), 196-210. 
Kazancı, F. (2018). Türkiye'de faizsiz bankacılık prensiplerine uygun teverruk pazarı: Ürün İhtisas Borsası. Journal of Islamic Economics and Finance 2018, 4(1), 17-47.

Köprü, M. F. (2015). Lisanslı depoculuk ve elektronik ürün senedi. Vergide Gündem, Ekonomist. sh, 60 .

Latham and Watkins (2015). The sukuk handbook: a guide to structuring sukuk. Second Edition.

Mızrak, G. (2008). Ürün ihtisas borsacılığı sisteminde lisanslı depoculuğun yeri, Ordu Ticaret Borsası, Mart 2008.

MKK (Merkezi Kayıt Kurulușu) (2017a). "Elektronik ürün senedi esasları”.

https://www.mkk.com.tr/file/Genel-Mektuplar-Dosyalari/Gm628-Ek-1 12.05.2020.

MKK (Merkezi Kayıt Kuruluşu) (2017b). "MKS uygulama düzenlemeleri hakkında bilgilendirme”. https://www.mkk.com.tr/tr/genel-mektup/744 01.10.2017.

Resmi Gazete (2010). "Kira sertifikalarına ve varlık kiralama şirketlerine ilişkin esaslar hakkında tebliğ", Sayı: 27359, https://www.resmigazete.gov.tr/eskiler/2010/04/20100401-15.htm 12.05.2020.

Resmi Gazete (2011). “Elektronik ürün senedi yönetmeliği”, Sayı: 28110, http://www resmigazete.gov.tr/eskiler/2011/11/20111112-12.htm 12.05.2020.

Resmi Gazete, (2013). “Kira sertifikaları tebliği”, Sayı: 28670, https://www.resmi gazete.gov.tr/eskiler /2013/06/20130607-14.htm 12.05.2020.

Resmi Gazete, (2017). “Ürün İhtisas Borsasının kuruluş, faaliyet, işleyiş ve Denetim, usul ve esasları hakkında yönetmenlik", Sayı: 30150, https://www.resmigazete. gov.tr/eskiler/2017/08/ 20170810-2.htm 25.01.2021.

Rizvi, S.A.R., Bacha, O.I., \& Mirakhor, A. (2016). Public finance and Islamic capital markets: theory and application. Springer.

Soeleman, S. \& Lestari, S. D. (2014). The role of sukuk financing for sustainable development of smallholder farmers. Australasian Accounting, Business and Finance Journal, 8(5), 79-92.

Takasbank (2020a). “Elektronik ürün senedi.” https://www.takasbank.com.tr/tr/hizmetler/hizmet-verilen-piyasalar/ticaret-borsalari-ve-lisansli-d epoculuk-elektronik-urun-senetleri-elus/genel-tanim 05.05.2020.

Takasbank (2020b). "Elektronik ürün senedi işlem hacim ve adetleri.”

https://www.takasbank.com.tr/tr/istatistikler/elektronik-urun-senedi-islemleri-ile-ilgili-istatistiki-bilgiler

\subsubsection{1.}

Tarkim (2020). “Tarkim'e 42 milyon TL.lik yeni kaynak.” http://www.tarimkredi.org. tr/index.php/ 
TMO (2018). “TMO'dan sukuk ihracı.” http://www.tmo.gov.tr/Main.aspx?ID=11071 05.05.2020.

TÜRIB (2020). "Kurumsal." https://www.turib.com.tr/Kurumsal.aspx?id=home 14.05.2020. USAID (2002). Regional commodity exchange initiative, phase 1, Vol. 2, ACDI/VOCA - USAID, Belgrade, Serbia.

USAID (2011). Dematerialization of warehouse receipts in the commodity markets, report, USAID Business Enabling Project, USAID, Washington, DC, p. 7, https:// www.usaid.gov/26.01.2019.

Vasiljevic, Z., Zakic, V., Bojcevski, M. \& Kovacevic, V. (2014). Importance of establishing the agricultural products storage system for third parties in the function of agribusiness system improvement. Proceedings Of Papers, 317.

Yurtoğlu, B.İ. (2015). Ürün senedinin tarım sektörünün finansmanındaki rolü. $M S c$ Tezi, TC Başkent Üniversitesi, Ankara. 
